Rev. Ryszard Ficek ${ }^{1}$

https://orcid.org/0000-0001-5238-6767; rficek@optonline.net

Katolicki Uniwersytet Lubelski Jana Pawła II

\title{
Christian and Culture in the Personalist Thought of Stefan Wyszyński
}

\begin{abstract}
Due to the multi-faceted nature of Stefan Wyszyński's personalistic concept, this article focuses on the Christian vision of culture. In this context, attention was drawn to how personalism can constitute the basis for shaping culture, especially to contemporary (post-) modern reality. The conducted analysis of the vision of culture places it to the facts of the Christian life. In this sense, creative activity for culture should be seen in the context of realizing the fullness of the human personality not only in the temporal dimension but also in the supernatural. It allows the human person to join the current of civilization and cultural changes and enable a person to discover the right place in the dynamically changing realities of the modern world.
\end{abstract}

Keywords: Stefan Wyszyński, personalism, culture, evangelization, postmodernism

\section{Streszczenie}

Chrześcijanin i kultura w personalistycznej myśli Stefana Wyszyńskiego

Ze względu na wieloaspektowość personalistycznej koncepcji Stefana Wyszyńskiego niniejszy artykuł jest skoncentrowany na chrześcijańskiej wizji kultury. W tym kontekście zwrócono uwagę na to, w jakim zakresie personalizm może stanowić

1 Rev. Ryszard Ficek S.T.D. - Ph.D., Long-term lecturer of moral theology, Catholic social science, and political science at Jordan University College/Tanzania. Catholic priest incardinated to the Diocese of Rockville Center/NY. Research interests: moral theology, cultural anthropology, church history, international relations. Recent book publications: Tanzania: narodziny i funkcjonowanie państwa, Torun 2007; Christians in Socio-Political Life: An Applied Analysis of the Theological Anthropology of Cardinal Stefan Wyszyniski, Primate of Poland, Torun 2020; Zaangażowanie chrześcijan w życie publiczne w kontekście nauczania kardynała Stefana Wyszyńskiego, Lublin 2020; Primate of the Millennium: Cardinal Stefan Wyszyński, Life and Legacy, Toruń 2021. 
podstawę do kształtowania kultury, zwłaszcza w odniesieniu do współczesnej rzeczywistości postmodernistycznej. Przeprowadzona analiza wizji kultury usytułowuje ją w odniesieniu do realiów życia chrześcijańskiego. W tym sensie, twórczą aktywność na rzecz kultury należy widzieć w kontekście realizacji pełni osobowości człowieka nie tylko w wymiarze doczesnym, ale także nadprzyrodzonym. Umożliwia to włączenie się osoby ludzkiej w nurt zachodzących przemian cywilizacyjno-kulturowych, ale równeż pozwala człowiekowi odkryć właściwe miejsce w dynamicznie zmieniających się realiach współczesnego świata.

Słowa kluczowe: Stefan Wyszyński, personalizm, kultura, ewangelizacja, postmodernizm

An essential dimension of the personalistic concept of Christian culture by Wyszyński - understood as the comprehensive humanization of human activity and the entire reality of the created world - is its integral character. Analyzing socio-cultural structures, therefore, cannot be reduced only to the category of progress, a purely material-temporal reality, a scientific-technical civilization guided by the principles of utilitarianism, and economic profit and loss account recognized in terms of "liquid postmodernity." A reductionist vision of culture rooted in a false conception of man and the world is not only unable to meet man's needs and aspirations, but - by showing a tendency to dominate over human person - may lead to the degradation of essential dimensions of human life.

As a result, only a personalistic Christian culture makes it possible to realize man's personal fullness in temporal and supernatural dimensions. Therefore, Wyszyński's Christian vision of culture puts the human person at the center of his interests. Thus, a man becomes its principal subject, goal, and sense of all creative human activity. Although a human person cannot live and function in isolation from culture, neither can we speak of an authentic culture isolated from the background of the whole truth about man and the world in which he lives.

Understood from the perspective of personalism, culture becomes a special gift thanks to which a person can fulfill himself and the social dimension. At the same time, it is a fundamental task to create a space for an authentically humanistic culture capable of shaping the human person according to his vocation. It is possible thanks to the sphere 
of personal values which, while serving to human being man and all structures of social life, condition the transformation of the whole reality of the world in the perspective of "a new heaven and a new earth" (cf. 2 Pt 3:13; Rev 21:1).

This is expressed primarily through cooperation with the God-Creator in the work of improving the temporal world. Completing creation's perspective with the mystery of the Incarnation and Redemption made by Jesus Christ is the crowning achievement of the saving history of man's relationship with God. Therefore, culture understood from the creative-salvation perspective is an essential dimension of the relationship of the human person to God, it emphasizes the unique dignity of man and his vocation understood as the full realization of the person in the individual and social dimension - and thus the humanization of the entire earthly reality in the spirit of the Christ's Gospel.

\section{Faith, Culture and the Phenomenon of Human Person}

In personalistic philosophical and theological anthropology, the human person is an exceptionally complex and mysterious being, having multidimensional relations with the internal and external world. As Wyszyński states, man is "a person, and he is a rational and free being. He is the master of creation." ${ }^{2}$ In this sense, the human person is open to the reality of other people, to the "mental world" with which are related: cognition, understanding, reflecting, awareness, intellect, reasoning, building thoughts individually or - in communion - with others, intuitive or rational interpenetration reality and finding out the truth. ${ }^{3}$ The human person is also constituted and enriched by the sphere

2 S. Wyszyński, Społeczność przyrodzona i nadprzyrodzona. II Konferencja Akademicka. Warszawa - kościót św. Anny 16.02.1957, in: S. Wyszyński, Kazania i przemówienia autoryzowane 1956-1981, t. 1-67, p. 61 (Archiwum Instytutu Prymasowskiego w Warszawie, 2).

3 As a rational and free being, the human person becomes an active evaluating and value-creating entity. In Christian culture, a man appears as a unique and mysterious person, but at the same time close to the world. It is this world that becomes the place where the human person is its principal subject. Thus, he can fulfill his humanity and achieve his appropriate goal. "Apart from a man - according to the Wyszyński - there is no personality, 
of will, with which are related, among others: the possibility of making decisions, the ambivalence of good-evil, making decisions in conscience, choosing values and organizing them into a kind of hierarchy, rejecting anti-values, striving for the goals set for oneself self-determination, any creative and liberal activity, an "challenging" attitude towards reality. ${ }^{4}$ The spirituality of a person is also enhanced with the various kinds of emotions and affections as well as their expressions. ${ }^{5}$

In other words, the human person, created by God, is a miracle of existence and shares something of the Three Divine Persons' Self-Existence. He exists in particular reality enjoying a "mysterious" dimension of life, that is: he has his own "interior and exterior," he is active and passive towards the world, he has his content (e.g., through the memory and imagination), as well as history and "transcendent-history," he can express his-self through "word," work, deed, and all his spiritual and material accomplishment. Therefore, a man is not only the composition of the body and the soul but also a kind of "transcendence" directed towards absoluteness and infinity. In this sense, a man is an absolute existential objectification of being with the possibility of internalization and a certain self-transcendence towards a new form of existence in God, without material boundaries. Besides, a human person has an inherent development opportunity but also inevitable irreversibility. As a result, he becomes more and more himself. Moreover, he is a "movement towards himself" as well as "towards other people." 6

no rationality, and no freedom" (S. Wyszyński, Społeczność przyrodzona i nadprzyrodzona, t. 1-67, p. 61 [Archiwum Instytutu Prymasowskiego w Warszawie, 2]).

4 Cf. S. Wyszyński, Bóg-Człowiekiem, aby człowiek był... Bogiem. Do inteligencji katolickiej, Warszawa-Miodowa 14.01.1970, in: S. Wyszyński, „Idzie nowych ludzi plemię...”. Wybór przemówień i rozważań, Poznań-Warszawa 1973, p. 48-49; Cz.S. Bartnik, „Osoba” w filozofii i teologii, Lublin 2017, p. 14-15.

5 Cf. S. Wyszyński, Najważniejszą wartością na świecie jest człowiek. Do delegacji NSZZ „Solidarność" Region Mazowsze 19.10.1980, in: S. Wyszyński, Nauczanie społeczne 1946-1981, Warszawa 1990, p. 962-963; Cf. J. Karczewska, Wychowanie chrześcijańskie w ujęciu Stefana Kunowskiego, Lublin 2006, p. 122-135 (mps pracy doktorskiej, Archiwum KUL).

6 Cf. S. Wyszyński, Konstytucja pastoralna o obecności Kościoła w świecie wspótczesnym, Warszawa - bazylika św. Jana 20.03.1966, in: S. Wyszyński, Kazania i przemówienia autoryzowane 1956-1981, p. 119-120 (Archiwum Instytutu Prymasowskiego w Warszawie, 1-67); S. Kowalczyk, Zarys filozofii człowieka, Sandomierz 1990, p. 198-213. 
The human person is entirely constituted by love understood as "communion of one's own world" with God and other people, and - secondarily - with all living beings, with the whole world, as well as the entire cosmos (universe). A person can discover and marvel at God's beauty radiating out over all of the breathtaking reality of the created world, including the beauty present in other human persons. Experiencing beauty is not an expression of stagnation for a person. Still, it gives him the strength to improve spiritually and create as well as display his own and proper role in life. It is, therefore, a power in the process of personalization, leading to a higher and more spiritually advanced stage of existence. ${ }^{7}$

Personalism attempts to avoid creating only fragmentary and incomplete definitions of culture. It is because such understanding of culture often focuses on only one of the elements, e.g., on the improvement of a person (moral and spiritual progress), or the community (even its organization in terms of legislation and regulation), or the world (development of technology or work organization). On the other hand, in Wyszyński's personalist system, one looks for a constitutive element of culture. In short, culture is understood as the humanization of life, humanization, and personalization of man and the world. It is the relationship of man to himself and all reality. In a sense, man culminates in culture, and through it, he responds to God's command to make the earth "subject to himself" (cf. Genesis 1:28).

In personalism, the scopes of cultures coincide with the contents of the human phenomenon. It is about an individual person, and, therefore, also about an individual and "personal" culture (microculture), which is a way of human self-realization; it also indicates a "social person" (e.g., family, nation, region) and the way he is conceived in the world (macroculture). In a broad sense, referring to the entire cultural space-time,

Cf. S. Wyszyński, O katolickiej woli życia. List pasterski na Wielkanoc 1947, in: S. Wyszyński, Nauczanie społeczne 1946-1981, Warszawa 1990, p. 33-34; Cz.S. Bartnik, „Osoba” w filozofii i teologii, 14; S. Wyszyński, Zarys myśli teologicznej Kardynała Wyszyńskiego, „Ateneum Kapłańskie” 97 (1981), p. 226-227. 
it also relates to the cultures of different epochs, the culture of humanity, as well as the historical world (megaculture). ${ }^{8}$

Since man has his own history, also cultures have their own past (they are born, develop and die out). And although sometimes different forms of culture collide with each other, affect each other positively or negatively, penetrate or disappear, the whole of humanity creates a common "universal culture." Moreover, just like human life has a biological, psychological, and spiritual dimension, one can also speak analogically about material culture (e.g., work, technology, products), about civilization (e.g., the social, community dimension of life), and spiritual culture (e.g., shaping the idea of God and cultivating the highest values along with morality). ${ }^{9}$

In the personalist view, the entire impersonal world is also a kind of interpersonal language in which God addresses a particular man. The human person learns this language and responds to God through a religious act - including his entire complex existential structure and using things, events, his whole life.$^{10}$ Faith is, therefore, an immense, intellectual, and whole-person synthesis of man on the level of his cognitions, information, knowledge, experiences, culture, art, poetry, and life. It is also "a powerful will to live, an impulse to throw oneself out of the visible and phenomenal sphere towards something invisible and supra-phenomenal, it is the basis for the" over-possible "self-realization of the human person, individual and social."11

In the personalistic sense, there is natural faith as well as supernatural faith, which is God's grace. Christianity has supernatural faith: man's whole relationship with Christ and, through him, with the entire Trinity. It leads, with human participation, to imitate Christ in the human person

8 Cf. S. Wyszyński, Kamienie węgielne budowane na górach świętych. Na Jasnej Górze po powrocie z uwięzienia (2.11.1956), in: S. Wyszyński, Nauczanie społeczne 1946-1981, Warszawa 1990, p. 63-65; Cz.S. Bartnik, Personalizm, Lublin 2008, p. 450-451.

9 Cf. Cz.S. Bartnik, Personalizm, p. 450-451.

10 Cf. R. Ficek, (Post-) Modernity and Christian Culture: In the Context of the Personalism of Stefan Cardinal Wyszyński, "Roczniki Kulturoznawcze" 11 (2020), p. 59-63.

${ }_{11}$ Cf. R. Ficek, (Post-) Modernity and Christian Culture: In the Context of the Personalism of Stefan Cardinal Wyszyński, p. 81-84. 
(cf. 1 Cor 15:49). As a result, man receives eternal life (cf. Jn 3:15-16), the gift of God's childhood - a new reality in man created by the Holy Spirit. ${ }^{12}$ However, even the very genuine faith introduces order and stability into the world, rational laws, and - especially - the grace of faith given from God.

\section{Faith and Culture: Correlations, Associations, and Mutual Influences}

Nowadays, some contemporary intellectuals, especially those engaged in postmodern discourse, oppose faith - and religion in general to culture and assert that faith is not related to culture. It is understood as even displaying the role of a kind of anti-culture. ${ }^{13}$ Wyszyński rightly

12 Cf. Cz.S. Bartnik, Bóg a ateizm, Lublin 2002, p. 133-134; M. Rusecki, Istota i geneza religii, Warszawa 1989, p. 228.

13 Postmodern discourse, however, is broadly based on the following principles: (1) First, anti-historicism, which is the rejection (condemnation) of tradition and, associated with it, historical thinking. Although the "historical trips" of postmodernists go back to the times of Plato and Aristotle (understood in Plato's way of thinking), the most criticized is Descartes and the extremely rationalist current of post-Cartesian thought, as well as the earlier historic utopism and later ideologism, which became the principles of (social) philosophy in the Enlightenment-from its cognitive and anthropological optimism and its teleological historiosophy, according to which history has a transcendent sense-goal-that is why in the writings of postmodernists we find the most anti-Enlightenment rhetoric. (2) Secondly, anti-essentialism (anti-fundamentalism or anti-foundationalism), which consists of rejecting the modernist dogma of the existence of the so-called "unshakable principles" or the so-called "permanent"-ontological, cognitive, moral, artistic, and religious. The belief in the existence of such "constants" is often called by postmodernists the "error of centrism": logos-centrism, theo-centrism, or-as in feminism-phallus-centrism. Those mentioned above "unshakable principles" were treated in modernism as universal model causes of human civilization and cultural activities, which led to the totalization and mechanization of social life and the alienation of its fundamental structures; the so-called judgmental philosophies that arose from the spirit of modernism could only create nightmarish Leviathan states (K. Popper). Antisessentialism is generally expressed in the catchy psychological "obituary" presented in popular slogans heralding the coming of the era of the so-called "death" of culture-God, man, science, morality, or art. In this case, the word "death" means that the traditional ideas and concepts of God, man, and morality are logically "dead," that is, they can no longer generate culture. In other words, humanity is in the phase of the so-called "exhaustion of opportunities" and thus reached the end of its own history. (3) Third, anti-discriminatoryism (anti-binarism, anti-dualism, anti-positionism), that is, the negation 
opposes this view and takes the position that - of course - faith and culture must be distinguished from each other but not separated. The nature of religion and culture differ significantly (religion is not part of the culture, and culture is not a "sub-discipline" of religion). Nevertheless, the religious act and the cultural act are combined in the same subject. ${ }^{14}$ Moreover, for religion to develop as a personal relationship with God, one must go through a cultural niche in which man forms his relations with the world, himself, and others. Therefore, culture appears functionally "earlier" than religion (faith), even though the relationship with God-Creator is ontologically prior. ${ }^{15}$

Nevertheless, a person's multidimensional activity means that the sphere of culture - understood as a specifically human reality - requires direct involvement. It is expressed primarily by the fact that, thanks to cognition, the human person "assimilates" and interiorizes the existing world, enriching himself with the content of reality understood in this way. Intellectualizing the existing fact and assimilating it in a human way improves a person with interiorized contents, which allows him to use them and, as a result, "come out of himself" in the act of voluntary action. It has its direct expression in the creative act. Thus, the

of the modernist myth of oppositions, e.g., subject-object; mind-body; reason-feelings; cognition-action; truth false; good evil; beauty, ugliness. According to postmodernists, the oppositional way of thinking "obsession with binarism"-leads to the emergence of undecidable problems in the culture, e.g., "mind-body problem" or the question of the definition of truth in culture, and results in the petrification of human life, and thus unjustified privileging of recognized ideals (values), and condemning others, i.e., intolerance. Cf. H. Kiereś, Postmodernizm: rzeczywistość czy kreacja, in: Poznanie bytów, czy ustalenie sensów? Zadania wspótczesnej metafizyki, red. A. Maryniarczyk, M.J. Gądek, Lublin, 2016, p. 177-179; R. Ficek, (Post-) Modernity and Christian Culture: In the Context of the Personalism of Stefan Cardinal Wyszyński, "Roczniki Kulturoznawcze" 11 (2020), p. 59-63.

14 Cf. S. Wyszyński, Zadania i środki oddziaływania Kościoła w Polsce w zakresie kształtowania kultury społeczno-katolickiej, Warszawa - kościół św. Anny, 15.01.1971, in: S. Wyszyński, Kazania i przemówienia autoryzowane 1956-1981, t. 1-67, p. 59-60 (Archiwum Instytutu Prymasowskiego w Warszawie, 36).

15 However, an act of faith affirming God's existence is possible without a developed material culture or civilization. Still, it presupposes at least an essential spiritual culture (the ability to go beyond self-awareness towards the absolute "You." Cf. Cz.S. Bartnik, Personalizm, p. 452-453. 
human being's dynamic nature, expressed in the need to improve, finds the right conditions in which a man can be fulfilled as a person. ${ }^{16}$

Over the centuries, however, a very close relationship has been observed between culture and religion, expressed in the process of mutual interaction and perception. Thus, one cannot comprehend the cultural achievements of society until one understands the religious beliefs that underlie them. Also, for the personalist vision of culture, religion is a tremendous and principal unifying force. It is the guardian of tradition, protects moral laws, educates, and teaches wisdom. In this sense, the encounter of Christianity with culture becomes a process of breaching the fabric of human behavior, models of life, way of thinking, and acting. This process appears to be universal, even though it has different characters, dividing this practically globally uniform approach into several sub-currents with a specific color and particular focus in different situations. In this context, we should also understand Wyszyński's statement: "The level of unifying culture is higher than that of separating culture. All paths of this culture lead through human nature, the nation, the state, and the church community." 17 "For everything came out of the unity of God, everything was created through one paternal love, and with the help of this love, everything is to return to this unity." ${ }^{18}$ The humanizing function of culture - developing man in all his properties - can be accurate, however, as long as the culture guarantees an integral concept of man as a spiritual and material being, temporal and yet oriented towards eternity, living in a time but called beyond all time, rational and therefore free, whose freedom is rooted in reason.

In other words, culture and religion differ in that culture relates to nature and the world, and faith relates to the Absolute and the Transcendent. Personalism defines the mutual dependence of religion and culture as follows: an "earlier" cultural act conditions the act of complete religiosity. The religiosity of culture exists only in a secondary sense (and only

16 Cf. A.F. Dziuba, Humanizująca funkcja kultury. Z nauczania kardynała Stefana Wyszyńskiego Prymasa Polski, Warszawa 2013, p. 37-44.

17 S. Wyszyński, Nie oczekujemy życia łatwego, Podczas ingresu do katedry lubelskiej 26.05.1946, in: S. Wyszyński, Nauczanie społeczne 1946-1981, Warszawa 1990, p. 10.

18 S. Wyszyński, Nie oczekujemy życia łatwego, p. 9. 
when religion displays a leading role in a given community). ${ }^{19}$ Therefore, it can be said on a personalist basis that both interpenetrate each other. Thus, both positions - "religion defines culture" and "culture defines religion" - should be taken complementarily. Neither of them, taken separately, fully describes the interactions between culture and religion. Understood in a complementary way, however, both aspects allow us to speak of "religion of culture" or "culture of religion." In this context, we talk about "secular culture" (cultura saecularis) and "sacred culture" (cultura sacra), a particular example of which would be Christian culture (cultura christiana).$^{20}$ Religious culture can arise by "raising" an existing culture. It can also be "born" by the community of faith. The essential point is that without culture, religion is mute, and without religion, culture is devoid of higher spiritual aspirations.

\section{Atheism, Nonbelief, and Anti-Culture: \\ The Dangerous Treats of Spiritual-Cultural Life}

In the personalist system of Stefan Wyszyński, human spiritual life is understood as the highest way of experiencing religiosity. When the personalization of the relationship with the God-Creator reaches its zenith and touches the depth of the "self" of the human person (then, "I" am the entire personal relationship to God), then one can speak of spiritual life. Nevertheless, this spiritual development is not linear and easy to describe. Today it is often understood as epektasis: a man being lifted up in his personality and human integrity. Thus, the spiritual life is not the culture itself (even on a higher level), nor the religion itself (if it were not deeply personalized and open to cultural activity). The proper culture-religion dyad serves to make man begin to live a spiritual life par excellence precisely as personal (e.g., through culture, man develops concepts related to faith, creates ideas of perfection, overcomes prejudices, updates the understanding of ethical norms, discovers the

19 Podobnie też akt etyczny (wybór moralny) jest nabudowany na akcie kulturowym. Cf. Cz.S. Bartnik, Personalizm, p.452-454.

20 Cf. Cz.S. Bartnik, Teologia kultury, p. 132-137. 
essence of Revelation). ${ }^{21}$ In the spiritual life, one can also perceive the individual and social dimensions (in this context, one talks about Christian spirituality schools).

In opposition to faith (religion), there is incomplete professing of faith, total unbelief, or even anti-faith (i.e., consciously and voluntarily fighting against faith). It can be said, however, that not every external lack of faith proves that a given person is an "unbeliever." The Christian faith (although not realized) may be possessed by non-practicing people; people considered externally as atheists (for example, even the believer himself may experience some deficiency in his own faith); followers of other religions, etc. ${ }^{22}$ However, complete atheism can only be spoken of when man rejects God on three levels: intellectual, volitional, and active. If there is no simultaneous negation in these three dimensions, we should not speak so much of man's atheism as of his internal incoherence. Complete faith is the affirmation of God in these three mentioned levels; it is an intrapersonal acceptance of a personal God, even up to the authenticity of deification, to participation in the mystical experience of God's Persons.

The opposite of culture (having three layers: anthropologization, humanization, and personalization) appears to be anti-culture (and with it in the reverse order: depersonalization, dehumanization, and finally de-anthropologization - shifting its identity in the ontic, physical, and biological spheres). ${ }^{23}$ In this context, spiritual culture (the one with the highest existential rank, efficiency, and fruitfulness, containing morality and leading man towards self-interpretation and self-mathematization) is influenced by religion and anti-religion, as well as ethics, and anti-ethics, values, and anti-values. In other words, it is threatened by many negative factors. ${ }^{24}$

Cf. Cz.S. Bartnik, Teologia kultury, p. 136.

22 Cf. R. Ficek, (Post-) Modernity and Christian Culture, p. 76-80.

23 Cf. Cz.S. Bartnik, Teologia kultury, p. 139.

24 Cf. R. Ficek, Moral Renewal as a Socio-Religious Imperative and the Destructive Actions of an Oppressive Totalitarian State: in the Context of Cardinal Stefan Wyszyński's Personalistic Concept of Social Life, "Roczniki Teologiczne" 67 (2020) no. 5, p. 56-57. 
In this context, culture understood as a whole is not confessional in itself but can be thematized in a Christian way. The removal of spiritual culture today, as well as faith from everyday life, will result in the breakdown of all human communication, the moral fall of individuals and all authorities, a negation of God and all values, and finally, the man himself. Today's world is threatened by an immoral civilization, making "the state of cave life" may endanger the man of tomorrow. ${ }^{25}$

The entire culture-faith relationship is realized in history, so it is subject to the laws of history and can take various forms. A lot depends on understanding these concepts themselves because there are different forms of culture, as well as religions built on faith are also diverse. Ancient cultures were built almost entirely on natural faith in God. In human history, atheistic cultures were only fragmentary and very few, although there were atheistic elements in every great civilization. Now, we have an era of cultures aiming at an atheistic form, in which, at most, those elements related to religion may appear incidental. ${ }^{26}$ Yet even here, the main foundations of secular culture take the form of new religious myths, albeit ones that are expressed in almost secular mythologies. After all, therefore, the faith-religion dyad is not broken. Even contemporary atheistic culture does not exist without a religious or pseudo-religious form.

Therefore, the personalistic hermeneutics depicts the complexity of the relationship between faith and culture. Moreover, it reveals their essential role in the process of personalizing the world and creating

25 Cf. S. Wyszyński, o zagrożeniu moralności narodu. List pasterski na wielki post 1968, in: S. Wyszyński, Nauczanie społeczne 1946-1981, Warszawa 1990, p. 343-344; id., Apel Synodu w obronie praw człowieka. Po powrocie z Synodu Biskupów, Warszawa 26.01.1975, in: S. Wyszyński, Nauczanie społeczne 1946-1981, Warszawa 1990, p. 619-626; S. Wyszyński, Problemy życia społecznego w Polsce. Do duszpasterzy młodzieży męskiej 29 XII 1975, in: S. Wyszyński, Nauczanie społeczne 1946-1981, Warszawa 1990, p. 669-672.

26 Cf. S. Wyszyński, „Res sacra homo”. Podczas jubileuszu świętego Wincentego á Paulo w Krakowie 27.09.1960, in: S. Wyszyński, Nauczanie społeczne 1946-1981, Warszawa 1990, p. 152-153.; S. Wyszyński, Konstytucja Pastoralna o obecności Kościoła w świecie wspótczesnym, p. 104-109. Many intellectuals today believe that belief in God alienates man. It has been argued that God (even the very idea of His existence) is a threat to man. However, it results from a reorientation of the doctrinal and existential perspective of the human person. Cf. S. Kowalczyk, Filozofia kultury, Lublin 2005, p. 159. 
personal communion for ultimate fulfillment in eternity, in the relationship of love with God's people. One should express the hope that contemporary man will not lack faith and spiritual strength to create a higher culture, form a communion of persons, and grow through religion and culture in love for God, for all people, and the entire earthly reality. ${ }^{27}$

\section{Personalization and Socialization through Faith and Culture}

In this context, the question arises: what is the relationship between culture and an individual and social person (e.g., a nation)? Does culture shape the person, or does it work the other way around: the person shapes culture? Cardinal Wyszyński claims that the human person occupies the central place in the entire reality of the created world. So, it is a specific person, society, and Nation that shape the culture and, thus, realizes their personal existence. In this context, culture is understood as a reflection of and is constituted by individual persons, as well as a Nation and other communities, and, at the same time, it is a movement towards the future. In this way, by expressing himself through culture, a man opens himself both to his inner spiritual dimension and to the outside world. That is why culturogenesis becomes, at the same time, the core of human personalization and socialization, the transformation of human nature into a person and community of persons. Thus culture has an active dimension (i.e., active and deliberate creation of culture by individual persons) and a passive aspect in the sense of being a sum of cultural experiences). It also contains a balance of all outcomes (cultural materialization) oriented towards the personal "creation" of a human being at the individual and social level. Therefore, culture - especially human work - helps the individual man to shape his entire personality (personalization of human beings). ${ }^{28}$

According to Wyszyński, the "common" and "community-forming" nature of culture consists of personal human qualities, gifts of reason, will, heart, upbringing, education, and life experience. In other words,

27 Cf. Cz.S. Bartnik, Hemeneutyka personalistyczna, Lublin 1993.

28 Cf. A.F. Dziuba, Humanizująca funkcja kultury, p. 63-69. 
everything that a person inherits and assimilates from the family, Nation, professional work, and well-organized state life. ${ }^{29}$ In this context, appreciation, and approval of interpersonal relations in culture - emphasizing the family that educates to culture, through the Nation that is united by culture, to the whole of humanity, for which authentic culture, especially Christian, which is a synonym of peace - is a fundamental aspect of the Wyszyński's teaching. ${ }^{30}$

From the personalist perspective, however, the cultural act is earlier than the religious (faith) as well as a moral act. For that reason, it draws attention to the great practical importance of such a state of affairs. Consequently, faith (religiosity) should be advanced and cultivated not only by multiplying pious acts but, first of all, by developing and dynamizing higher spiritual culture. On the other hand, culture can also be acquired through religion. Nevertheless, one should be aware not to "strengthen" harmful cultural elements with acts of faith. At the same time, faith and culture are indispensable for each other and should be developed in parallel. Improving culture helps to create more profound religiosity, though faith prevents culture from becoming stunted and abets its rise to the "absolute" realm. ${ }^{31}$

Both phenomena (faith and culture) serve the personalization and socialization of a human being. Personalization is understood as the optimal development of a man in himself and the community. In contrast, socialization can be seen as shaping the appropriate relationship between an "individual" and a "social" person. Culture and faith are needed for growth because if religion is lacking culture turns quickly into a dangerous pseudo-religion and - sooner or later - into anti-culture. When culture is lacking, religion degenerates and becomes more or less an unbelief or destructive cult. In both cases (unbelief and anti-culture),

29 Cf. S. Wyszyński, Kościół wspólnototwórczy, Warszawa-Miodowa 4.08.1970, in: S. Wyszyński, Kazania i przemówienia autoryzowane 1956-1981, t. 1-67, p. 145-156 (Archiwum Instytutu Prymasowskiego w Warszawie, 34).

30 Cf. S. Wyszyński, Sumienie prawe u podstaw odnowy życia narodowego, Poznań-Warszawa, p. 993.

31 Cf. Cz.S. Bartnik, Personalizm, p. 454-455. 
the process of human development halts or goes back - then the human person spiritually dies. ${ }^{32}$

In this sense, the culture-religion dyad is double-subjected in the personal world: the individual and social (community) dimensions. Yet, faith and particular culture belong to a specific human environment. Moreover, an "appropriate" culture is necessary to evangelize nations (inculturation displays an important role here). On the other hand, the lack of spiritual life causes many cultures to disappear (as well as many nations, tribes, and tribes). Therefore, it must be said that the lack of faith as well as the lack of culture affects not only an individual man but also destroys a specific human community, and now and then regrettably - leads to its destruction. ${ }^{33}$

\section{Conclusion}

As the fundamental dimension of human life and activity, culture plays a vital role in the entire teaching of Cardinal Wyszyński. The personalist perspective allows him to see the actual source and goal of an authentically humanistic culture in the human person. In Wyszyński's understanding, culture means all human activity. As a result, he reasonably and intentionally sees all reality towards the development of the human person in all its dimensions. Therefore he understands culture as permeating the entire existence of the human person and, in a way, manifests its essence.

However, only an integral connection between culture and Christianity can create an authentically humanistic culture in this understanding. Therefore, the involvement of the human person in the reality of culture, combined with the richness of faith and grace, forms a specific synthesis that allows not only the full realization of man as a person. Involvement

32 Cf. S. Wyszyński, Głos biskupów polskich w obronie zagrożonego bytu Narodu, Warszawa, 28.01.1971, in: S. Wyszyński, Listy Pasterskie Episkopatu Polski 1945-1974, Paris 1975, p. 623-628; S. Wyszyński, Do artystów scen warszawskich, Warszawa, Dom Arcybiskupów, 10.01.1971, in: S. Wyszyński, Z rozważań nad kultura ojczysta, Warszawa 1998, p. 109-117.

${ }_{33}$ Cf. R. Ficek, Christians in Socio-Political Life: An Applied Analysis of the Theological Anthropology of Cardinal Stefan Wyszyński, Primate of Poland, Toruń 2020, p. 314-320. 
in culture also enables the world's reality to be changed, giving it a genuinely human appearance. Thus, a personalistically understood culture becomes a reality in which man expresses himselffor himself and other people.

The Christian understanding of commitment to culture allows us to shape all complex levels of social life. The testimonies of human cultural activity - realizing human spirituality - simultaneously become an expression of the personalistic sphere of value, also specified in human life's community dimension. Through goodness, truth, and beauty, the human spirit transforms the reality of the world of matter and is realized in works of culture and social structures. It aims not only to shape human maturity, improve others, and humanize the world but also to look at the cultural activity of the human person through the prism of the creative-salvific plan of God's providence.

In this context, Cardinal Wyszyński displays the role of Christian culture in the dimension of all social structures, especially in the Nation. A look at the history of the Nation from a salvation history perspective emphasizes the fundamental value of Christian culture, which not only enables and stimulates the comprehensive development of ever more perfect forms of social and national life and allows us to meet the challenges of history, but also becomes a fundamental condition for preserving the identity and sovereignty of the Nation. The Church plays a vital role in shaping a personalistically understood Christian culture. The involvement of Christians in culture-creating activities is thus included in the process of shaping human civilization. Therefore, it becomes a kind of evangelization of the world. Bringing God-Man into the world's life creates the foundations of authentically humanist culture, enabling all humanity's comprehensive development based on truly personalist values.

\section{Bibliography}

Bartnik Cz.S., Bóg i ateizm, Lublin 2002.

Bartnik Cz. S., Hemeneutyka personalistyczna, Lublin 1993.

Bartnik Cz. S., „Osoba” w filozofii i teologii, Lublin 2017.

Bartnik Cz.S., Personalizm, Lublin 2008.

Bartnik Cz.S., Teologia kultury, Lublin 1999.

Bartnik Cz.S., Zarys myśli teologicznej Kardynała Wyszyńskiego, "Ateneum Kapłańskie” 97 (1981), p. 226-227. 
Dziuba A.F., Humanizująca funkcja kultury, Z nauczania kardynała Stefana Wyszyńskiego Prymasa Polski, Warszawa 2013.

Ficek R., (Post-) Modernity and Christian Culture: In the Context of the Personalism of Stefan Cardinal Wyszyński, "Roczniki Kulturoznawcze" 11 (2020), p. 49-89.

Ficek R., Christians in Socio-Political Life: An Applied Analysis of the Theological Anthropology of Cardinal Stefan Wyszyński, Primate of Poland, Torun 2020.

Ficek R., Moral Renewal as a Socio-Religious Imperative and the Destructive Actions of an Oppressive Totalitarian State: in the Context of Cardinal Stefan Wyszyński's Personalistic Concept of Social Life, "Roczniki Teologiczne" 67 (2020) no. 5, p. 39-61.

Karczewska J., Wychowanie chrześsijańskie w ujęciu Stefana Kunowskiego, Lublin 2006 (mps pracy doktorskiej, Archiwum KUL).

Kiereś H., Postmodernizm: rzeczywistość czy kreacja, in: Poznanie bytów, czy ustalenie sensów? Zadania współczesnej metafizyki, red. A. Maryniarczyk, M.J. Gądek, Lublin 2016, p. 175-190.

Kowalczyk S., Filozofia kultury, Lublin 2005.

Kowalczyk S., Zarys filozofii człowieka, Sandomierz 1990.

Rusecki M., Istota i geneza religii, Warszawa 1989.

Wyszyński S., Kazania i przemówienia autoryzowane 1956-1981 (Archiwum Instytutu Prymasa Stefana Kardynała Wyszyńskiego w Warszawie, 1-67).

Wyszyński S., Apel Synodu w obronie praw człowieka. Po powrocie z Synodu Biskupów, Warszawa 26 I 1975, in: S. Wyszyński, Nauczanie społeczne 1946-1981, Warszawa 1990, p. 619-626.

Wyszyński S., Bóg-Człowiekiem, aby człowiek był... Bogiem. Do inteligencji katolickiej, Warszawa-Miodowa 14.01.1970, in: S. Wyszyński, „Idzie nowych ludzi plemię...”. Wybór przemówień i rozważań, Poznań-Warszawa 1973, p. 46-50.

Wyszyński S., Głos biskupów polskich w obronie zagrożonego bytu Narodu, Warszawa, 28.01.1971, in: S. Wyszyński, Listy Pasterskie Episkopatu Polski 1945-1974, Paris 1975, p. 623-628.

Wyszyński S., Do artystów scen warszawskich, Warszawa, Dom Arcybiskupów, 10.01.1971, in: S. Wyszyński, Z rozważań nad kultura ojczysta, Warszawa 1998, p. 109-117.

Wyszyński S., Kamienie węgielne budowane na górach świętych. Na Jasnej Górze po powrocie z uwięzienia (2.11.1956), in: S. Wyszyński, Nauczanie społeczne 1946-1981, Warszawa 1990, p. 62-67.

Wyszyński S., Konstytucja Pastoralna o obecności Kościoła w świecie współczesnym. Warszawa - bazylika św. Jana 20. 03. 1966, in: S. Wyszyński, Kazania i przemówienia autoryzowane 1956-1981, p. 103-124 (Archiwum Instytutu Prymasowskiego w Warszawie, 1-67).

Wyszyński S., Kościót wspólnototwórczy. Warszawa-Miodowa 4.08.1970, in: S. Wyszyński, Kazania i przemówienia autoryzowane 1956-1981, t. 1-67, p. 145-156 (Archiwum Instytutu Prymasowskiego w Warszawie, 34).

Wyszyński S., Najważniejsza wartością na świecie jest człowiek, Do delegacji NSZZ „Solidarność” Region Mazowsze 19.10.1980, in: S. Wyszyński, Nauczanie społeczne 1946-1981, Warszawa 1990, p. 960-965. 


\section{Rev. Ryszard Ficek}

Wyszyński S., Nie oczekujemy życia łatwego, Podczas ingresu do katedry lubelskiej 26.05.1946, in: S. Wyszyński, Nauczanie spoleczne 1946-1981, Warszawa 1990, p. 9-13.

Wyszyński S., O katolickiej woli życia. List pasterskina Wielkanoc 1947, in: S. Wyszyński, Nauczanie społeczne 1946-1981, Warszawa 1990, p. 29-40.

Wyszyński S., O zagrożeniu moralności narodu. List pasterski na wielki post 1968, in: S. Wyszyński, Nauczanie społeczne 1946-1981, Warszawa 1990, p. 343-344.

Wyszyński S., Problemy życia społecznego w Polsce. Do duszpasterzy młodzieży męskiej 29 XII 1975, in: S. Wyszyński, Nauczanie społeczne 1946-1981, Warszawa 1990, p. 669-672.

Wyszyński S., "Res sacra homo". Podczas jubileuszu świętego Wincentego á Paulo w Krakowie 27. 09. 1960, in: S. Wyszyński, Nauczanie społeczne 1946-1981, Warszawa 1990, p. $150-156$.

Wyszyński S., Społeczność przyrodzona i nadprzyrodzona. II Konferencja Akademicka, Warszawa - kościół św. Anny 16.02.1957, in: S. Wyszyński, Kazania i przemówienia autoryzowane 1956-1981, t. 1-67, p. 57-79 (Archiwum Instytutu Prymasowskiego w Warszawie, 2).

Wyszyński S., Sumienie prawe u podstaw odnowy życia narodowego, Poznań 1981.

Wyszyński S., Zadania iśrodki oddziaływania Kościoła w Polsce w zakresie ksztattowania kultury społeczno-katolickiej, Warszawa - kościół św. Anny, 15.01.1971, in: S. Wyszyński, Kazania i przemówienia autoryzowane 1956-1981, t. 1-67, p. 56-71 (Archiwum Instytutu Prymasowskiego w Warszawie, 36). 